\title{
THE UNHEALTHY DELIGHTS: ONLINE GAMES - DOES PERSONALITY TRAITS AND NEEDS SATISFACTION PLAYS A ROLE?
}

\author{
Novita Liesera ${ }^{1}$, Sri Tiatri ${ }^{2}$ dan Niken Widiastuti ${ }^{3}$ \\ ${ }^{1}$ Faculty of Psychology, Universitas Tarumanagara Jakarta \\ Email:Lieserax@gmail.com \\ ${ }^{2}$ Faculty of Psychology, Universitas Tarumanagara Jakarta \\ Email: sri.tiatri@untar.ac.id \\ ${ }^{3}$ Faculty of Psychology, Universitas Tarumanagara Jakarta \\ Email: nikenw@fpsi.untar.ac.id
}

\begin{abstract}
ABSTRAK
Bermain game online secara berlebihan dapat memberikan dampak buruk secara fisik dan psikis bagi pemainnya. Online game engagement merupakan indikator generik dari keterlibatan pemain dalam bermain game online (Brockmyer, et al., 2009). Studi sebelumnya menemukan bahwa tiga dari lima trait kepribadian Five Factor Model terkait dengan pemenuhan kebutuhan psikologis (Teng, 2009) dan game online dapat menjadi sarana untuk memenuhi kebutuhan psikologis tersebut (Przybylski, Rigby, \& Ryan, 2010). Studi ini bertujuan untuk mengetahui hubungan dari trait kepribadian dan online game engagement pada remaja di Jakarta dengan basic psychological needs satisfaction sebagai mediator. Responden studi ini ialah remaja berusia $15-18$ tahun $(\mathrm{n}=333)$ yang dipilih melalui non-probability convenience sampling. Metode penelitian ini adalah kuantitatif dengan media kuesioner. Data dianalisis dengan metode regresi. Hasil menunjukkan basic psychological needs satisfaction memediasi hubungan trait kepribadian dan online game engagement hanya untuk trait conscientiousness $\left(r^{2}=0.050, p<0.01\right)$ dan trait neuroticism $\left(\mathrm{r}^{2}=0.051, \mathrm{p}<0.01\right)$.
\end{abstract}

Kata kunci: trait kepribadian, big five factors of personality, online game engagement, basic psychological needs satisfaction

\section{ABSTRACT}

Playing too many online games could harm the player both physically and mentally. Online game engagement is a generic indicator of one's involvement in online game playing (Brockmyer, Fox, Curtiss, McBroom, Burkhart, \& Pidruzny, 2009). The previous study found that three out of five traits from the Five Factor Model correlates with psychological needs fulfillment (Teng, 2009). Online games serve as a mean to fulfill these psychological needs (Przybylski, Rigby, \& Ryan, 2010). This study attempts to understand the correlation between personality traits and the online game engagement of adolescents in Jakarta with basic psychological needs satisfaction as a mediator. The participants of this study are adolescent gamers age between 15 to 18 years $(n=333)$. Quantitative methods and questionnaires are used to gather information from participants. Regression result shows that basic psychological needs satisfaction mediates personality traits and online game engagement. Out of five traits, basic psychological needs satisfaction only mediates for conscientiousness $(r 2=0.050, p<0.01)$ and neuroticism $(r 2=$ $0.051, p<0.01)$.

Keywords: personality traits, big five factors of personality, online game engagement, basic psychological needs satisfaction

\section{INTRODUCTION}

\section{Background of the study}

Playing games has been a method of recreation for people from various age groups. With the development of technology, people begin to shift from traditional games to online games. A study shows that an estimate of $10.15 \%$ cases of online game addiction among Indonesian school students gamers (Jap, Tiatri, Jaya, \& Suteja, 2013). Adolescence is a phase in discovering one's identity. In the process, the adolescent is interested to try new experiences and challenges (Santrock, 2011). This characteristic is utilised by online game developers in developing their games. Online games are designed attractively with various challenges to attract adolescent players. Online game also serves as a media to socialise with other players of similar interest (Young, 2009). 
Despite the popularity of online games, playing intensively in the long term have a negative effect both physically and mentally. Physically, over-gaming may result in backache, headaches, migraines, a decrease in eye-power, and increase the risk of glaucoma (Jenkins, 2012; Torsheim, Eriksson, Schnohr, Hansen, Bjarnason, \& Välimaa, 2010). Radiation from online game media may cause dermatitis, skin irritation, and reduce a player's fertility (Jenkins, 2012; Setiawan, 2014; Suhendi, 2013). The player may also risk from repetitive strain injury which may lead to permanent deformity if not properly treated (Dube, 2013; Jenkins, 2012). Continuous online gaming can also lead to death among adolescent gamers. The lack of physical activity during gaming can lead to deep vein thrombosis (McCrum, 2015) and heart failure (BBC, 2005; Cooper, 2012; Hunt \& Ng, 2015; Shu-ting \& Po-hsuan, 2012). Playing online games can also affect the player psychologically. An adolescent may engage in criminal activities in order to play (Jap, Tiatri, Jaya, \& Suteja, 2013; Truta, 2007), re-enacting the unrealistic game scene in real life (Leung, 2005), or even commit suicide in order to 'meet' their favourite game character in the afterlife (China Daily, 2005; Fox News, 2006).

A study conducted by Griffiths, Davies, and Chappell (2004) found that adolescent players are more likely than adults to prioritise gaming over other important life areas such as education. Study shows that the amount of time spent on gaming is inversely proportional to time spent doing school work (Jap, Tiatri, Jaya, \& Suteja, 2013). Such behaviour would affect their studies negatively (Griffiths, Davies, \& Chappell, 2004; Nuhan, 2016). Overly engaged in online games would automatically reduce the available time for an adolescent to socialise in real life. In the long run, players may become uncomfortable in socialising face-to-face as they have become too comfortable socialising through a 'screen' media in online games. The player may unconsciously isolate themselves from their friends in real life (Suhendi, 2013; Young, 2009).

The downside of playing online games occurs when players are excessively engaged in playing. Engagement refers to the drive to do a certain action/activity repeatedly (Schoenau-Fog, 2011). The higher one's engagement in online games, the longer the time spent playing. A successful online game is one that can motivate the players to engage in play. However, a study shows that the longer one spends on online games, the lower one's well-being and ability to adapt to their environment (Przybylski, Rigby, \& Ryan, 2010).

A study shows that high extraversion and openness to experience are commonly found among online game players (Teng, 2008). Players with high extraversion are drawn to the chance of connecting with players of similar interest to expand their friendship pool. Players with high openness to experience enjoy the challenges online games provide to quench their thirst of curiosity and adventure (John \& Srivastava, 1999; McCrae \& John, 1991; Wildermuth, 2013; Woods \& Sofat, 2013). However, the personality trait itself is too general to act as a single predictor to engagement among online game players. The previous study shows that personality trait is significantly correlated to online game addiction but not engagement. However, online game addiction and engagement are significantly correlated (Charlton \& Danforth, 2008).

An online game, a study found, serves as a means to satisfy one's basic psychological needs. Basic psychological needs consist of three aspects, i.e. competence, autonomy, and relatedness (Ryan \& Deci, 2000). Unfulfilled basic psychological needs in real life can be compensated by playing online games. First, playing online games can give the player a sense of competence, i.e. the nature of online game designed from simpler level to harder ones give a player time to learn and adapt with the working of the game and hence master the required skill to pass the challenge. 
Online games also provide feedbacks such as performance graphs, leaderboards, or badges to show the player's progress (Przybylski, Rigby, \& Ryan, 2010; Sailer, Hense, Mayr, \& Mandl, 2017). A study shows that the intensity of use increases when one perceives the self-competent in a particular activity (Touati \& Baek, 2018). Second, online games provide a degree of freedom in various aspects such as avatar design and gaming strategies. Online games with storylines give players a sense of meaningfulness on the action/decision taken, regardless of whether there is actually a choice or not. This helps to fulfil the unsatisfied needs of autonomy (Przybylski, Rigby, \& Ryan, 2010; Sailer, Hense, Mayr, \& Mandl, 2017). Third, online games serve as a media to meet and connect with new people from various backgrounds, i.e. a mean to fulfil the unsatisfied basic need of relatedness. Online games with storylines, especially those aiming for the same goal, can give a sense of teammates although the team members may be non-players, thus fulfilling the need of relatedness (Przybylski, Rigby, \& Ryan, 2010; Sailer, Hense, Mayr, \& Mandl, 2017).

\section{Research question}

Does basic psychological needs satisfaction mediate the online game engagement and personality trait?

\section{RESEARCH METHOD Research participants}

The participants of this research are adolescents, aging between $15-18$ years old $(M=16.43$, $S D=.86$ ). There are 180 male and 153 female high school students participating in this study. The participating students are active online game players who play regularly. Out of 333 participants, $59.2 \%$ play online games for more than 7 hours/week. The sampling technique used is nonprobability convenience sampling.

\section{Measures}

There are three scales used in this study, i.e. (a) Game Engagement Questionnaire, (b) Basic Psychological Needs Satisfaction, and (c) Big Five Inventory. The three instruments show good reliability $\left(\alpha>0.6, \mathrm{r}_{\mathrm{it}}>0.2\right)$ except for Big Five Inventory's agreeableness $(\alpha=0.580)$.

Brockmyer, et al., (2009) develop the Game Engagement Questionnaire to measure a player's involvement in online games. One of the original 19 items is split into 2 items to increase specification. This scale is rated on a 4-point Likert scale from 'Not at All True' (1) to 'Very True' (4). The item-total correlation of the 20-items is .294- .682 with a reliability of $\alpha=.880$.

Basic Psychological Needs Scale is developed based on Deci and Ryan (2000) selfdetermination theory. The 21-item scale measures the three basic needs, namely competence (6 items), autonomy ( 7 items), and relatedness ( 8 items). This scale is rated on a 4-point Likert scale from 'Not at All True' (1) to 'Very True' (4). The item-total correlation of the 21-items is $.372-.549$ with a reliability of $\alpha=.793$.

The Big Five Inventory is based on John and Srivastava (1999) theory on personality trait. The 44-item scale measures the five personality traits, namely extraversion, agreeableness, conscientiousness, neuroticism, and openness to experience. This scale is rated on a 4-point Likert scale from 'Not at All True' (1) to 'Very True' (4). 5 items are removed due to its low validity $\left(r_{i t}<0.2\right)$. The item-total correlation from each trait varies from .224 to .618. The items measuring each trait shows good reliability $(\alpha>.6)$ except for agreeableness $(\alpha=.580)$.

\section{Statistical Analysis}


Collected data are processed by SPSS software. First, we check for the reliability of the three scales used by using Cronbach's Alpha. The validity of each item is measured by item-total correlation. Multiple linear regression is used to measure the mediation.

\section{RESULTS AND DISCUSSION}

\section{Result}

Statistical analysis shows that the personality trait agreeableness and openness to experience does not spread on normal curve $\mathrm{p}<.05$ ) and hence excluded from further analysis. Pearson correlation shows that there is no significant correlation between extraversion and online game engagement ( $p>.05)$ hence both traits also excluded from further analysis.

Single linear regression shows that both conscientiousness and neuroticism significantly influence both online game engagement and basic psychological needs satisfaction $(p<.05)$.

Table 1. Linear Regression Analysis Result

\begin{tabular}{|c|c|c|c|c|}
\hline \multirow[t]{2}{*}{ IV/DV } & \multicolumn{2}{|c|}{ Online Game Engagement } & \multicolumn{2}{|c|}{$\begin{array}{c}\text { Basic Psychological Needs } \\
\text { Satisfaction }\end{array}$} \\
\hline & $\mathbf{r}^{2}$ & sig. & $\mathbf{r}^{2}$ & sig. \\
\hline Basic Psychological Needs Satisfaction & $0.046 * *$ & 0.000 & & \\
\hline BFI Conscientiousnes & $0.015^{*}$ & 0.027 & $0.064 * *$ & 0.000 \\
\hline BFI Neuroticism & $0.025 * *$ & 0.004 & $0.100 * *$ & 0.000 \\
\hline
\end{tabular}

* regression is significant at 0.05 level

** regression is significant at 0.01 level

Multiple linear regression shows that the influence of both conscientiousness and neuroticism trait becomes insignificant with the presence of basic psychological needs satisfaction as the mediator ( $p>.05)$. This shows that basic psychological needs satisfaction completely mediates the two personality traits with online game engagement.

Table 2. Multiple Regression Analysis Result

\begin{tabular}{|c|c|c|c|c|c|}
\hline \multirow{3}{*}{ Variable } & \multicolumn{5}{|c|}{ Multiple Linear Regression } \\
\hline & \multirow{2}{*}{$\mathbf{r}^{2}$} & \multirow{2}{*}{$\mathbf{F}$} & \multirow{2}{*}{ sig } & \multicolumn{2}{|c|}{$\begin{array}{l}\text { Unstandardised } \\
\text { Coefficients }\end{array}$} \\
\hline & & & & $\boldsymbol{\beta}$ & sig \\
\hline $\begin{array}{l}\text { Conscientiousness + BPNS } \rightarrow \\
\text { Online Game Engagement }\end{array}$ & $0.050 * *$ & 8.774 & 0.000 & & \\
\hline Conscientiousness & & & & -0.087 & 0.195 \\
\hline $\begin{array}{l}\quad \text { BPNS } \\
\text { Neuroticism }+ \text { BPNS } \rightarrow \text { Online } \\
\text { Game Engagement }\end{array}$ & $0.051 * *$ & 8.750 & 0.000 & $-0.223 * *$ & 0.000 \\
\hline Neuroticism & & & & 0.106 & 0.066 \\
\hline BPNS & & & & $-0.193 * *$ & 0.003 \\
\hline
\end{tabular}

** regression significance at 0.01 level

\section{Discussion}

This study found that out of five personality traits, only conscientiousness and neuroticism are significantly correlated to online game engagement. The correlation between conscientiousness and online game engagement is significant and negative, which suggests that a player with low trait conscientiousness tends to experience online game engagement. Players with low trait conscientiousness are less likely to be able to control themselves and tend to be impulsive. 
Hence, it is more difficult for them to stop themselves from playing (John \& Srivastava, 1999; McCrae \& John, 1991; Wildermuth, 2013; Woods \& Sofat, 2013).

The correlation between neuroticism and online game engagement is significant and positive. Players with high neuroticism tend to be more engaged in online games. This may be caused by the dynamic situation in online games, acting as a stimulant to keep the player's enthusiasm in playing (Jeong \& Lee, 2015; John \& Srivastava, 1999; McCrae \& John, 1991; Wildermuth, 2013; Woods \& Sofat, 2013). This supports the study of Johnson dan Gardner (2010) which states that players with lower emotional stability tend to undergo immersion and presence (stages in online game engagement) when playing games online.

Basic psychological needs satisfaction fully mediates the relationship between trait conscientiousness and trait neuroticism towards online game engagement (complete mediation). The negative beta coefficient (standardised) indicates that the player whose basic psychological needs are less fulfilled are more likely to show higher engagement in online games. The result of this study supports the study of Przybylski, Rigby, and Ryan (2010) which elaborates on how features of an online game can be a medium to fulfill needs for autonomy, competence, and relatedness. The said study states that online games that can satisfy the basic psychological needs of their player, increases the immersion level (one of the stages of online game engagement). The capability of online games to fulfil those needs can be predictors whether or not players will replay the games (Przybylski, Rigby, \& Ryan, 2010).

A study by Teng (2009) states that individuals with high conscientiousness tend to have fulfilled their basic psychological needs. In terms of autonomy, players with high conscientiousness can effectively accomplish their routines and have spare time to do things they enjoy. In terms of competence, players with high conscientiousness have the perseverance to increase their skills to be able to finish their work well. In terms of relatedness, the needs of players with high conscientiousness are easily fulfilled due to their responsibility and reliability in a group (John \& Srivastava, 1999; Teng, 2009). Teng's study (2009) supported the result of this study, that is a low conscientiousness and lack of basic psychological needs increases the tendency towards online game engagement.

Conscientiousness and basic psychological needs satisfaction are only able to predict online game engagement up to 5\%. Neuroticism and basic psychological needs satisfaction could only predict online engagement up to $5.1 \%$. The remaining of almost $95 \%$ are predicted by other factors that are not covered yet by these studies such as the capacity of self-regulation (Collins, Freeman, \& Chamarro-Premuzic, 2011).

Basic psychological needs satisfaction does not mediate the impact of extraversion on online game engagement. This is due to the absence of influence or relationship between trait extraversion and online game engagement that can be mediated. The result partially supports the study of Charlton and Danforth (2008) who states that there is no relationship between a personality trait and online game engagement. The absence of this relationship could be caused by players with high or low extraversion levels to be engaged or not towards online games. Engagement can happen due to things like increasing association for high extraversion level players or as a media that they feel comfortable to express themselves by low extraversion level players. However, this can also be achieved through other media or different methods such as using social media. 
During data collection, researchers spoke to some respondent who admits they never or have stopped playing online games. Teenagers who confess they never play games online, states that online games are a waste of time and useless. Players who no longer play games, state that they have other activities and have no more time to play online games. From both groups who do not play online games, it can be concluded that engagement towards online games is a choice. If the players consider online games are important, they continue playing online games and develop engagement towards it. On the other hand, if they consider playing online games are merely an activity not worth doing, then they will not play or stop playing.

\section{CONCLUSION}

Out of five personality traits based on the Five Factor Models of Personality, there are two traits that are significantly correlated to online game engagement. Trait conscientiousness is negatively correlated to online game engagement while trait neuroticism is positively correlated to online game engagement. Basic psychological needs satisfaction thoroughly mediates the impact of trait conscientiousness and trait neuroticism towards online game addiction (complete mediation).

Future studies can further develop this study by several focusing on the stages of online game engagement in detail with other variables such as self-regulation. In-depth interviews can also be utilised to obtain deeper information on how online games fulfil basic psychological needs. Future studies can also further expand this study by using different participant criteria or other mediating variables.

Adolescent online game players are suggested to understand themselves better, spend less time playing online games and go for other activities such as exercising. Excessive engagement towards online games may develop to addiction, which is why adolescents are advised to be more aware of own gaming habit. If one finds themselves lacking the capability of self-control, it is better to seek aid from a trustworthy adult.

Educators and parents are recommended to understand better the psychological needs of teenagers and give them a chance to fulfill it. It needs to be emphasized that online games do not provide real psychological needs. These needs are better fulfilled in real life.

\section{ACKNOWLEDGEMENT}

I would like to express gratitude to Erik Wijaya and Ahmad Fuady for their assistance on regression analysis.

\section{REFERENCES}

BBC. (2005, August 10). S Korean dies after games session. BBC News. Retrieved from http://news.bbc.co.uk/2/hi/technology/4137782.stm

Brockmyer, J. H., Fox, C. M., Curtiss, K. A., McBroom, E., Burkhart, K. M., \& Pidruzny, J. N. (2009). The development of the Game Engagement Questionnaire: A measure of engagement in video game-playing. Journal of Experimental Social Psychology, 45, 624634.

Charlton, J. P. \& Danforth, I. D. W. (2008). Validating the distinction between computer addiction and engagement: Online game playing and personality. Behaviour and Information Technology, 29(6), 601-613.

China Daily. (2005, May 31). Young addict's suicide sounds stark warning. China.org. Retrieved from http://www.china.org.cn/english/life/130551.htm 
Collins, E., Freeman, J., \& Chamarro-Premuzic, T. (2011). Personality traits associated with problematic and non-problematic massively multiplayer online role playing game use. Personality and Individual Differences, 52, 133-138.

Cooper, R. (2012, February 03). Gamer lies dead in internet cafe for 9 hours before anyone notices. Daily Mail. Retrieved from http://www.dailymail.co.uk/news/article2096128/gamer-lies-dead-taiwan-internet-cafe-9-hours-notices.html

Dube, R. (2013, September 18). 5 dangerous gaming injuries and how to avoid them. Make Use Of. Retrieved from http://www.makeuseof.com/tag/5-dangerous-gaming-injuries-and-howto-avoid-them/

Fox News. (2006, May 12). Chinese 'Warcraft' game distributor sued over teen's suicide. Fox News. Retrieved from http://www.foxnews.com

Griffiths, M. D., Davies, M. N. O., \& Chappell, D. (2004). Online computer gaming: A comparison of adolescent and adult gamers. Journal of Adolescence, 27, 87-96.

Hunt, K. \& Ng, N. (2015, January 19). Man dies in Taiwan after 3-day online gaming binge. CNN. Retrieved from http://edition.cnn.com/2015/01/19/world/taiwan-gamer-death/

Jap, T., Tiatri, S., Jaya, E. S., \& Suteja, M. S. (2013). The development of Indonesian Online Game Addiction Questionnaire. PLoS ONE, 8(4): e61098. doi:10.1371/journal.pone.0061098

Jenkins, B. (2012, November 23). 10 shocking medical conditions caused by gaming. ODDEE.

Jeong, E. J. \& Lee, H. R. (2015). Addictive use due to personality: Focused on Big Five Personality Traits and game addiction. International Journal of Social, Behavioural, Educational, Economic, Business and Industrial Engineering, 9(6), 2002-2006.

John, O. P. \& Srivastava, S. (1999). The Big-Five trait taxonomy: History, Measurement, and theoretical perspectives. The Handbook of Personality: Theory and Research (2nd ed.) (Pervin, L. \& John, O. P. Eds.). The Guilford Press, New York

Johnson, D. \& Gardner, J. (2010). "Personality, motivation, and video games". 22nd Conference of the Computer-Human Interaction Special Interest Group of Australia on ComputerHuman Interaction, Queensland University of Technology, Brisbane, 22-26 November 2010.

Leung, R. (2005, March 04). Can a video game lead to murder?: Did 'Grand Theft Auto' cause one teenager to kill?. CBS News. Retrieved from http://www.cbsnews.com/news/can-avideo-game-lead-to-murder-04-03-2005

McCrae, R. R. \& John, O. P. (1991). An introduction to the Five-Factor Model and its applications. Journal of Personality, 60(2), 175-215.

McCrum, K. (2015, September 03). Tragic teen gamer dies after 'playing computer for 22 days in a row'. Mirror. Retrieved from http://www.mirror.co.uk/news/world-news/tragic-teengamer-dies-after-6373887

Nuhan, M. Y. G. (2016). Hubungan intensitas bermain game online dengan prestasi belajar siswa kelas IV sekolah dasar negeri jarakan Kabupaten Bantul, Yogyakarta. Jurnal Pendidikan Guru Sekolah Dasar, 6, 494-501.

Przybylski, A. K., Rigby, C. S., \& Ryan, R. M. (2010). A motivational model of video game engagement. Review of General Psychology, 14(2), 154-166.

Ryan, R. M. \& Deci, E. L. (2000), The darker and brighter sides of human existence: Basic psychological needs as a unifying concept. Psychological Inquiry, 11, 319-338.

Sailer, M., Hense, J. U., Mayr, S. K., \& Mandl, H. (2017). How gamification motivates: An experimental study of the effects of specific game design elements on psychological needs satisfaction. Computers in Human Behaviour, 69, 371-380.

Santrock, J. W. (2011). Educational Psychology. McGraw Hill, New York

Schoenau-Fog, H. (2011). "The player engagement process - An exploration of continuation desire in digital games". Proceedings of DiGRA 2011 Conference: Think Design Play. 
Setiawan, A. C. (2014, 14 Maret). Dampak negatif game online ditinjau dari beberapa segi. Keluarga.com. Diunduh dari https://keluarga.com/1403/dampak-negatif-game-onlineditinjau-dari-beberapa-segi

Shu-ting, C. \& Po-hsuan, W. (2014, February 04). Gamers ignore corpse in internet cafe. Taipei Times. Retrieved

from http://www.taipeitimes.com/news/front/archives/2012/02/04/2003524636

Suhendi, F. (2013). Mewaspadai pengaruh negatif radiasi komputer/laptop terhadap mata dan tubuh anda. Safety Sign. Diunduh dari www.safetysign.co.id/news/106/MewaspadaiPengaruh-Negatif-Radiasi-Komputer-Laptop-terhadap-Mata-dan-Tubuh-Anda

Teng, C. (2008). Personality differences between online game players and nonplayers in student sample. Cyber Psychology and Behaviour, 11(2), 232-234.

Teng, C. (2009). Online game player personality and real-life need fulfilment. International Journal of Cyber Society and Education, 2(2), 39-50.

Torsheim, T., Eriksson, L., Schnohr, C. W., Hansen, F., Bjarnason, T., \& Välimaa, R. (2010). Screen-based activities and physical complaints among adolescents from the Nordic countries. BMC Public Health, 10(324).

Touati, A. \& Baek, Y. (2018). What leads to player's enjoyment and achievement in a mobile learning game?. Journal of Educational Computing Research, 56(3), 344-368.

Truta, F. (2007). 13-year-old boy kills old woman over cash for online games. Softpedia. Retrieved from http://news.softpedia.com/news/13-year-old-boy-kills-old-woman-overcash-for-online-games-71503.html

Wildermuth, C. D. M. E. S. (2008). Engaged to serve: The relationship between employee engagement and the personality of human services professionals and paraprofessionals. Dissertation at Bowling Green State University for the fulfilment of Doctor of Education.

Woods, S. A. \& Sofat, J. A. (2013). Personality and engagement at work: the mediating role of psychological meaningfulness. Journal of Applied Social Psychology, 43(11), 2203-2210.

Young, K. (2009). Understanding online gaming addiction and treatment issues for adolescents. The American Journal of Family Therapy, 35, 355-372. 